\title{
Inhibition of MMP-2-Mediated Mast Cell Invasion by NF-KB Inhibitor DHMEQ in Mast Cells
}

\author{
Naruto Noma ${ }^{a}$ Masataka Asagiria Masatoshi Takeiria Saori Ohmae ${ }^{a}$ \\ Kenji Takemoto $^{a, b}$ Keiko Iwaisako ${ }^{c}$ Nagahiro Minato $^{d}$ Mari Maeda-Yamamoto $^{\text {e }}$ \\ Siro Simizu ${ }^{f}$ Kazuo Umezawag \\ a Innovation Center for Immunoregulation and Therapeutics, ${ }^{b}$ Division of Hepato-Biliary-Pancreatic Surgery and \\ Transplantation, Department of Surgery, Departments of ${ }^{\mathrm{C}}$ Target Therapy Oncology and ${ }^{\mathrm{d}}$ Immunology and Cell \\ Biology, Graduate School of Medicine, Kyoto University, Kyoto, ${ }^{e}$ Food Function Division, National Food Research \\ Institute, National Agriculture and Food Research Organization, Tsukuba, ${ }^{f}$ Department of Applied Chemistry, \\ Faculty of Science and Technology, Keio University, Yokohama, and ${ }^{9}$ Department of Molecular Target Medicine, \\ Aichi Medical University School of Medicine, Nagakute, Japan
}

\author{
Key Words \\ $(-)$-DHMEQ $\cdot$ NF-KB $\cdot$ MMP-2 $\cdot$ Invasion $\cdot$ Mast cell
}

\begin{abstract}
Background: Stimulation with antigen and IgE is known to activate NF-KB in mast cells. In the present research, we studied the role of NF-KB on cellular migration in mast cell-like $\mathrm{RBL}-2 \mathrm{H} 3$ cells and bone marrow-derived mast cells (BMMCs) using the NF-KB inhibitor (-)-DHMEQ. Methods: A Matrigel invasion chamber was used to evaluate cell migration. A PCR array was used to screen the expression of 84 key genes involved in cell migration. Results: (-)-DHMEQ inhibited antigen/lgE-induced NF-KB activation and expressions of its target genes such as IL-6 and TNF-a. (-)-DHMEQ was found to inhibit in vitro invasion toward the antigen without any toxicity. We then looked for NF-kB-dependent genes that would be important for mast cell invasion using the PCR array. (-)-DHMEQ was found to lower the expression of matrix metalloproteinase (MMP)-2. The MMP inhibitor GM6001 also inhibited cellular invasion toward the antigen. These effects of (-)-DHMEQ were obtained in both RBL-2H3 cells and BMMCs.
\end{abstract}

\section{KARGER 125}

(c) 2015 S. Karger AG, Base

$1018-2438 / 15 / 1662-0084 \$ 39.50 / 0$

E-Mail karger@karger.com

www.karger.com/iaa
Conclusions: These findings indicate that (-)-DHMEQ suppressed mast cell migration via the inhibition of NF-KBregulated MMP-2 expression.

(c) 2015 S. Karger AG, Basel

\section{Introduction}

Bronchial asthma, urticaria, angioedema, allergic rhinitis, and allergic conjunctivitis are all caused by type I allergic reactions. Type I allergic reaction is mediated by antigen-specific IgE-binding mast cell degranulation [1], and this reaction leads to anaphylactic shock when it takes place in the whole body [2].

Mast cells secrete leukotrienes, histamine and prostaglandins upon activation with antigen and IgE and play a central role in allergic reactions [3]. Allergic inflammation is characterized by tissue infiltration of inflamma-

Correspondence to: Dr. Kazuo Umezawa

Department of Molecular Target Medicine

Aichi Medical University School of Medicine

Nagakute 480-1195 (Japan)

E-Mail umezawa@ aichi-med-u.ac.jp

Co-Corresponding author: Dr. Masataka Asagiri

Innovation Center for Immunoregulation and Therapeutics

Graduate School of Medicine, Kyoto University

Kyoto 606-8501 (Japan)

E-Mail masa-asagiri@umin.org 
tory cells, including mast cells, lymphocytes and eosinophils [4]. It has previously been shown that rat basophilic leukemia RBL-2H3 cells sensitized with antigen-specific IgE migrate toward the antigen, and this migration is directional [4]. Moreover, mast cell invasion is not only involved in inflammation but also in cancer malignancy [5].

Activation of the FceRI receptor in mast cells induces the IKK-NF- $\kappa$ B pathway [6]. NF- $\kappa$ B activation mediated by IgE/DNP induces the expression of inflammatory cytokines such as TNF- $\alpha$ and IL-6 in RBL-2H3 cells [7]. In cancer cells, NF- $\kappa B$ activation also induces cell migration and invasion by inducing matrix metalloproteinase (MMP)-9, urokinase-type plasminogen activator and ICAM-1 [8]. On the other hand, the relationship between $\mathrm{NF}-\kappa \mathrm{B}$ activation and the motility of mast cells is unknown.

Previously, we designed and synthesized a novel NF$\kappa \mathrm{B}$ inhibitor, (-)-dehydroxymethylepoxyquinomicin, called (-)-DHMEQ (fig. 1a) [9]. DHMEQ is synthesized as its racemic form, and after chiral separation the $(-)$-DHMEQ enantiomer is about 10 times stronger than the (+)-DHMEQ enantiomer [10]. (-)-DHMEQ inhibits the translocation of NF- $\mathrm{KB}$ protein to the nucleus [11] and DNA binding activity of NF- $\kappa B$ by covalently binding to specific cysteine residues of the protein [12]. (-)-DHMEQ showed various anti-inflammatory effects on animal models, including rheumatoid arthritis [13] and renal inflammation [14].

In the present research, we found that the NF- $\kappa \mathrm{B}$ inhibitor (-)-DHMEQ inhibited IgE-sensitized cell invasion in mast cell-like RBL-2H3 cells and mouse bone marrow-derived mast cells and revealed the inhibitory mechanism.

\section{Materials and Methods}

\section{Materials}

(-)-DHMEQ was synthesized in our laboratory as previously described [10]. DNP-albumin conjugate, bovine, pan-MMP inhibitor GM6001 and the selective MMP-2 inhibitor cis-9-octadecenoyl-N-hydroxylamide (OA-Hy), were purchased from Calbiochem (Darmstadt, Germany). Monoclonal anti-dinitrophenyl antibody IgE SPE-7 and anti-MMP-2 antibody were purchased from Sigma (St. Louis, Mo., USA) and Daiichi Fine Chemical (Toyama, Japan), respectively.

\section{Cell Culture}

Rat basophilic leukemia RBL-2H3 cells were maintained in Dulbecco's modified Eagle's medium (Nissui Pharmaceutical Co. Ltd., Tokyo, Japan) supplemented with $10 \%(\mathrm{v} / \mathrm{v})$ heat-inactivated FBS, $200 \mathrm{U} / \mathrm{ml}$ penicillin G, $200 \mathrm{mg} / \mathrm{l}$ kanamycin, $600 \mathrm{mg} / \mathrm{l} \mathrm{L-glu-}$ tamine, and $2.25 \mathrm{~g} / 1 \mathrm{NaHCO}_{3}$ at $37^{\circ} \mathrm{C}$ in a humidified incubator with 5\% $\mathrm{CO}_{2}$. Mouse bone marrow-derived mast cells (BMMCs) were generated from 6-week-old C57BL/6 mice according to the method described previously [15]. Briefly, bone marrow cells in alpha modification of Eagle's medium ( $a-M E M$; Invitrogen, Carlsbad, Calif., USA) containing 10\% FBS, $100 \mathrm{U} / \mathrm{ml}$ penicillin G, 100 $\mu \mathrm{g} / \mathrm{ml}$ streptomycin, $1 \mathrm{~mm}$ sodium pyruvate, $0.1 \mathrm{mM}$ nonessential amino acid, and $50 \mu \mathrm{M} 2$-mercaptoethanol (Invitrogen) supplemented with $10 \mathrm{ng} / \mathrm{ml}$ mIL-3 (PeproTech, Rocky Hill, N.J., USA) were cultured at $37^{\circ} \mathrm{C}$ in a humidified atmosphere of $5 \% \mathrm{CO}_{2}$. Nonadherent cells were transferred every week for up to 4 weeks into fresh culture medium. BMMCs were used when $>95 \%$ of the cells were mast cells determined by flow cytometry for FceRIa expression and by toluidine blue staining.

\section{Cellular Invasion through Matrigel}

Assays were performed using a 24-well Matrigel invasion chamber with a pore size of $8.0 \mu \mathrm{m}$ (BD Biosciences, Bedford, MA) [16] or 24 -well cell culture inserts with 8 - $\mu$ m pore size filters (BD Biosciences) coated with $100 \mu \mathrm{l}$ of Matrigel (BD Biosciences) to form a thin continuous layer and allowed to solidify at $37^{\circ} \mathrm{C}$ for $1 \mathrm{~h}$ [17]. The lower compartment was filled with $500 \mu$ l of the serum-free medium, with or without the indicated concentration of DNP-BSA. RBL-2H3 cells $\left(2.0 \times 10^{5}\right)$ or BMMCs $\left(1.0 \times 10^{6}\right)$ were resuspended in $500 \mu \mathrm{l}$ of the same medium and placed in the upper part of the Matrigel plate. The cells were incubated for $24 \mathrm{~h}$ and then fixed and stained. Cells on the upper surface of the filter were removed mechanically by wiping with a cotton swab and, under light microscopic observation, the invasive phenotypes were determined by counting the cells that had migrated to the lower side of the filter. Three randomly selected fields were counted from each well and experiments were repeated 3 times. Cell growth was measured with Cell Counting Kit-8 (Dojindo Laboratories, Kumamoto, Japan) as previously described [18].

\section{Electrophoretic Mobility Shift Assay}

An electrophoretic mobility shift assay for NF- $\kappa B$ binding to DNA was carried out as described [12]. The DNA probes used for NF- $\kappa \mathrm{B}$ binding were the previously described double-stranded oligonucleotides [19] or NF- $\kappa$ B IRDye 700 oligonucleotides (LI-COR Biosciences, Lincoln, Nebr., USA).

RNA Isolation and Semiquantitative RT-PCR Analysis

Total RNA was extracted from RBL-2H3 cells using TRIzol reagent (Invitrogen). Reverse transcription was carried out with the High-Capacity cDNA Reverse Transcription Kit (Applied Biosystems, Carlsbad, Calif., USA). The cDNA was used for PCR amplification with rTaq DNA polymerase (Takara Bio, Shiga, Japan). The sequences of the primers used for semiquantitative RT-PCR, the numbers of cycles and the annealing temperatures are shown in online supplementary table 1 (for all online suppl. material, see www.karger.com/doi/10.1159/000371419).

\section{Real-Time PCR Array}

Total RNA was extracted from RBL-2H3 cells using RNeasy mini (Qiagen, Hilden, Germany). Reverse transcription was carried out at $42^{\circ} \mathrm{C}$ for $15 \mathrm{~min}$ with the RT2 First Strand Kit (Qiagen). The cDNA was used for PCR amplification with RT2 SYBR Green ROX qPCR Master Mix (Qiagen). The cDNA was added to the qPCR Master Mix and the aliquot mixture across the Rat Cell Motility PCR Array (Qiagen). Hprt1 was used as a housekeeping gene. Data analysis was carried out by the comparative Ct method. 


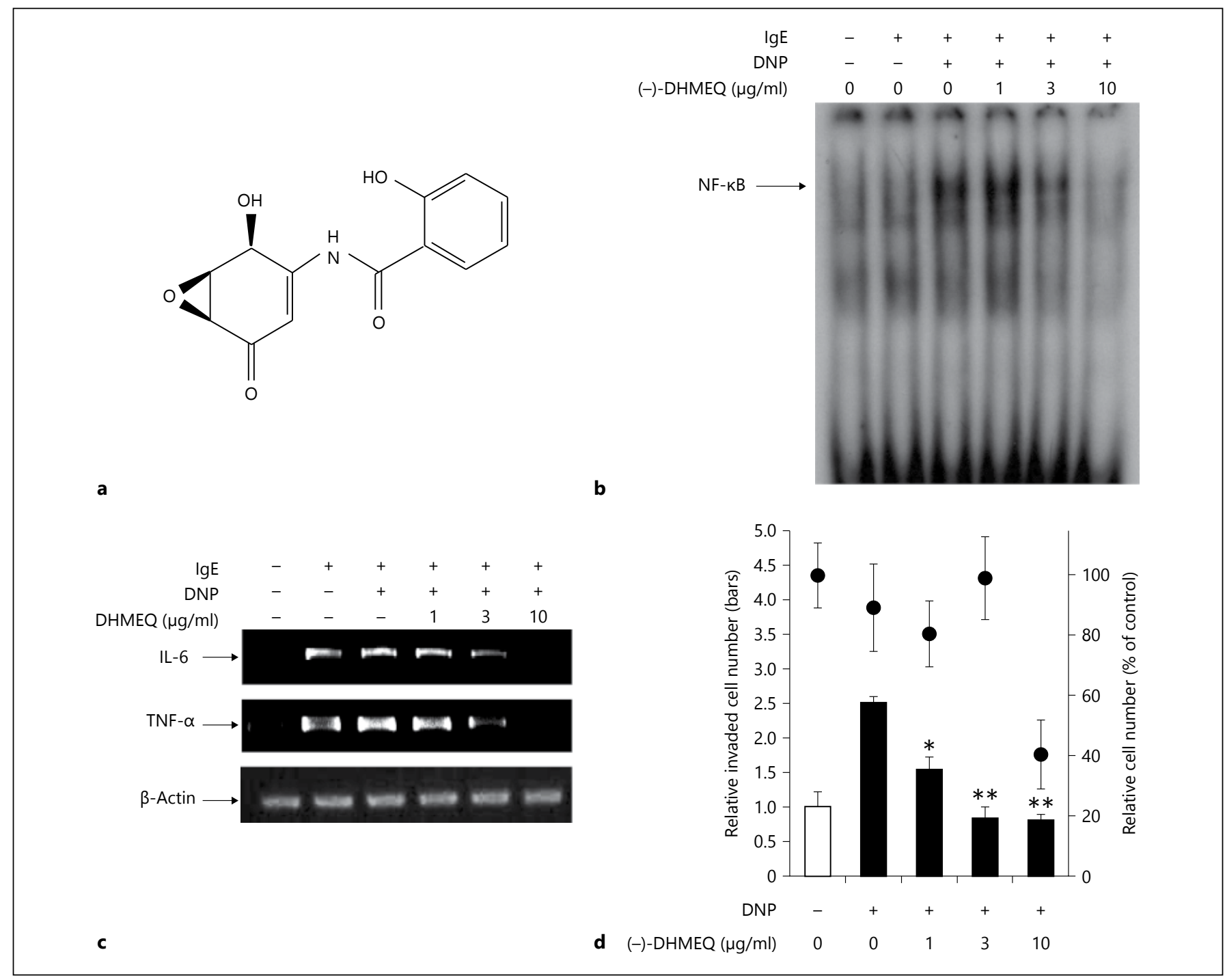

Fig. 1. Inhibition of cellular invasion by $\mathrm{NF}-\mathrm{\kappa B}$ inhibitor (-)-DHMEQ in IgE/DNP-stimulated RBL-2H3 cells. a Structure of (-)-DHMEQ. $\mathbf{b}$ Inhibition of NF- $\kappa B$. RBL-2H3 cells were sensitized with IgE for $20 \mathrm{~h}$. The cells were then treated with (-)-DHMEQ for $2 \mathrm{~h}$ and stimulated with DNP-BSA for $1 \mathrm{~h}$, and nuclear proteins were extracted. Nuclear proteins were mixed with $\mathrm{a}^{32} \mathrm{P}$-labeled $\kappa \mathrm{B}$ probe and applied on electrophoresis. $\mathrm{c}$ Inhibition of NF- $\kappa \mathrm{B}$-dependent gene expression. Cells were sensitized with $\operatorname{IgE}$ for $20 \mathrm{~h}$ and then treated with the indicated concentrations of (-)-DHMEQ for $4 \mathrm{~h}$ and DNP-BSA for $3 \mathrm{~h}$. Then, TNF- $\alpha$ and IL-6 mRNA expressions were assessed by semiquantitative RT-PCR.

\section{Results}

Inhibition of $N F-\kappa B$ and Migration by (-)-DHMEQ in RBL-2H3 Cells

IgE/DNP-BSA-induced NF- $\mathrm{NB}$ activation was inhibited by (-)-DHMEQ (fig. 1a) in rat mast cell-like RBL- d Inhibition of cellular invasion. IgE-sensitized cells were seeded on the upper chamber and treated with (-)-DHMEQ for $24 \mathrm{~h}$. The lower chamber was filled with serum-free medium, with or without $100 \mathrm{ng} / \mathrm{ml}$ DNP-BSA. Cells that migrated to the lower side of the membrane were counted (bars). The cell number is shown as a dark circle. The data are the mean \pm SD of 3 independent determinations. ${ }^{*} \mathrm{p}<0.05$, statistically significant difference between DNP-treated cells and DNP/(-)-DHMEQ $(1 \mu \mathrm{g} / \mathrm{ml})$-treated cells (Student's test); ${ }^{* *} \mathrm{p}<0.001$, statistically significant difference between DNP-treated cells and DNP/(-)-DHMEQ (3 or $10 \mu \mathrm{g} / \mathrm{ml})$ treated cells (Student's test).

$2 \mathrm{H} 3$ cells at its nontoxic concentrations (fig. 1b). It also inhibited NF- $\kappa$ B downstream genes such as TNF- $\alpha$ and IL-6 (fig. 1c). Moreover, (-)-DHMEQ was found to inhibit the migration of IgE-sensitized RBL-2H3 cells toward the antigen in a Matrigel chamber assay without any toxicity (fig. 1d).
Noma et al. 


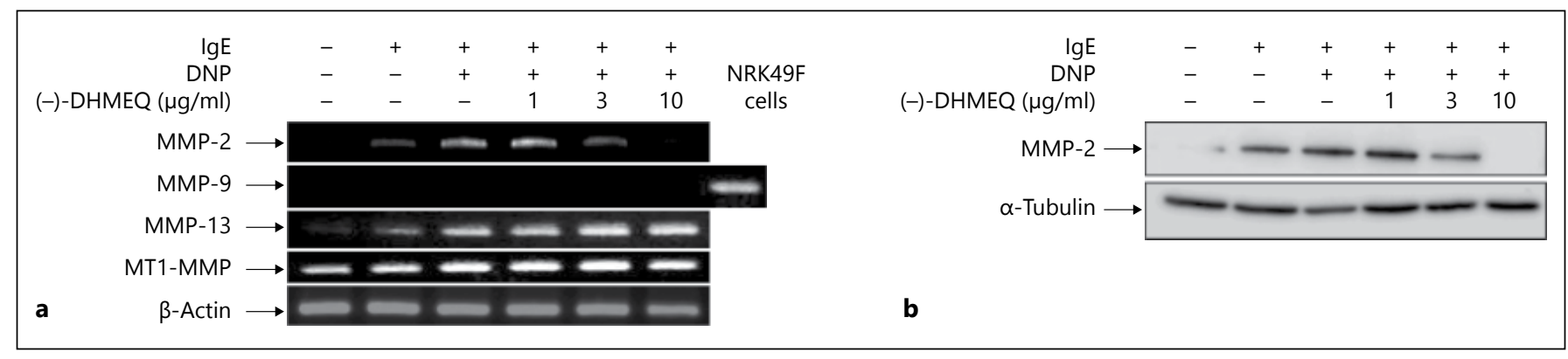

Fig. 2. Inhibition of MMP-2 expression by (-)-DHMEQ. a Effect on MMP mRNA expression. Cells were sensitized with IgE for $20 \mathrm{~h}$ and treated with the indicated concentrations of (-)-DHMEQ for $3 \mathrm{~h}$ and DNP-BSA for $1 \mathrm{~h}$. Then, MMP-2, MMP9, MMP-13, and MT1-MMP mRNA expressions were assessed by

Table 1. Motility-related genes downregulated by (-)-DHMEQ

Gene (Protein) names

Expression level (\% of control)

Mmp2 (matrix metalloproteinase-2, MMP-2) 22.2

Pak4 (serine/threonine-protein kinase PAK4) 41.2

Akt1 (AKT1 kinase) $\quad 49.3$

Cfl1 (cofilin-1) 51.1

Diaph1 (diaphanous homolog 1) 55.5

Igf1 (insulin-like growth factor 1, IGF-1) $\quad 56.3$

Cav1 (caveolin-1) 57.4

Arhgef7 (rho guanine nucleotide exchange factor 7)

Tgfb1 (transforming growth factor beta-1, TGF- $\beta 1)$

$\mathrm{Vcl}$ (vinculin)

62.4

62.9

RBL-2H3 cells were treated as described in Materials and Methods. The top 10 genes and names of the corresponding proteins downregulated by (-)-DHMEQ $(10 \mu \mathrm{g} / \mathrm{ml})$ are listed.

\section{Inhibition of MMP-2 Expression by (-)-DHMEQ}

We next searched for critical factors responsible for cell invasion that are regulated by NF- $\kappa \mathrm{B}$. Then, we searched for those specific genes using a real-time PCR array system arranged for cell motility. RBL-2H3 cells were treated with IgE/DNP with or without (-)-DHMEQ. We then compared the gene expression of (-)-DHMEQtreated and untreated cells. We evaluated 84 genes related to cell motility. Expressions of cell motility-related genes such as MMP-2, Pak4 and Akt1 were lowered by (-)-DHMEQ, as shown in table 1. Among them, we focused on MMP-2 expression in RBL-2H3 cells and analyzed it by semiquantitative RT-PCR. (-)-DHMEQ semiquantitative RT-PCR. b Inhibition of MMP-2 protein expression. Cells were sensitized with IgE for $20 \mathrm{~h}$ and treated with (-)-DHMEQ for $3 \mathrm{~h}$ and DNP-BSA for $2 \mathrm{~h}$. Total cell extracts were prepared and then subjected to immunoblotting.

inhibited IgE-DNP-induced MMP-2 expression in a dose-dependent manner, while it did not inhibit MMP13 and MT1-MMP expression in RBL-2H3 cells (fig. 2a). MMP-9 expression was not detected in RBL-2H3 cells, though it was detected in rat kidney NRK49F cells. Inhibition of MMP-2 expression by (-)-DHMEQ was also confirmed at the protein level (fig. 2b). To study whether MMP-2 mRNA transcription is directly regulated by NF- $\kappa B$, we employed a protein synthesis inhibitor, cycloheximide. Cycloheximide did not inhibit IgE/DNPinduced MMP-2 mRNA expression, indicating that MMP-2 expression was due to the binding of NF- $\kappa B$ to the MMP-2 promoter (online suppl. fig. 1).

\section{Inhibition of Cellular Invasion by MMP Inhibitor GM6001}

Next we studied whether MMP-2 is involved in RBL$2 \mathrm{H} 3$ invasion, and employed the MMP inhibitor GM6001, which is known to inhibit MMP-2 [20]. GM6001 inhibited IgE-sensitized cell invasion toward the antigen in RBL-2H3 cells, as shown in figure 3a. Moreover, cotreatment with GM6001 and (-)-DHMEQ did not show additive inhibition compared with (-)-DHMEQ alone or GM6001 alone (fig. 3a). In addition, the selective MMP-2 inhibitor OA-Hy also inhibited RBL-2H3 cell invasion, although this chemical is slightly toxic (fig. $3 \mathrm{~b}$ ).

\section{Inhibition of Cellular Invasion and MMP-2}

Expression by (-)-DHMEQ in Primary Culture Mouse Mast Cells

We prepared a primary culture of mouse mast cells, as described in Methods. We then studied the effect of (-)-DHMEQ on NF- $\kappa \mathrm{B}$ activity, MMP-2 expression and Matrigel invasion in these cells. (-)-DHMEQ inhib- 


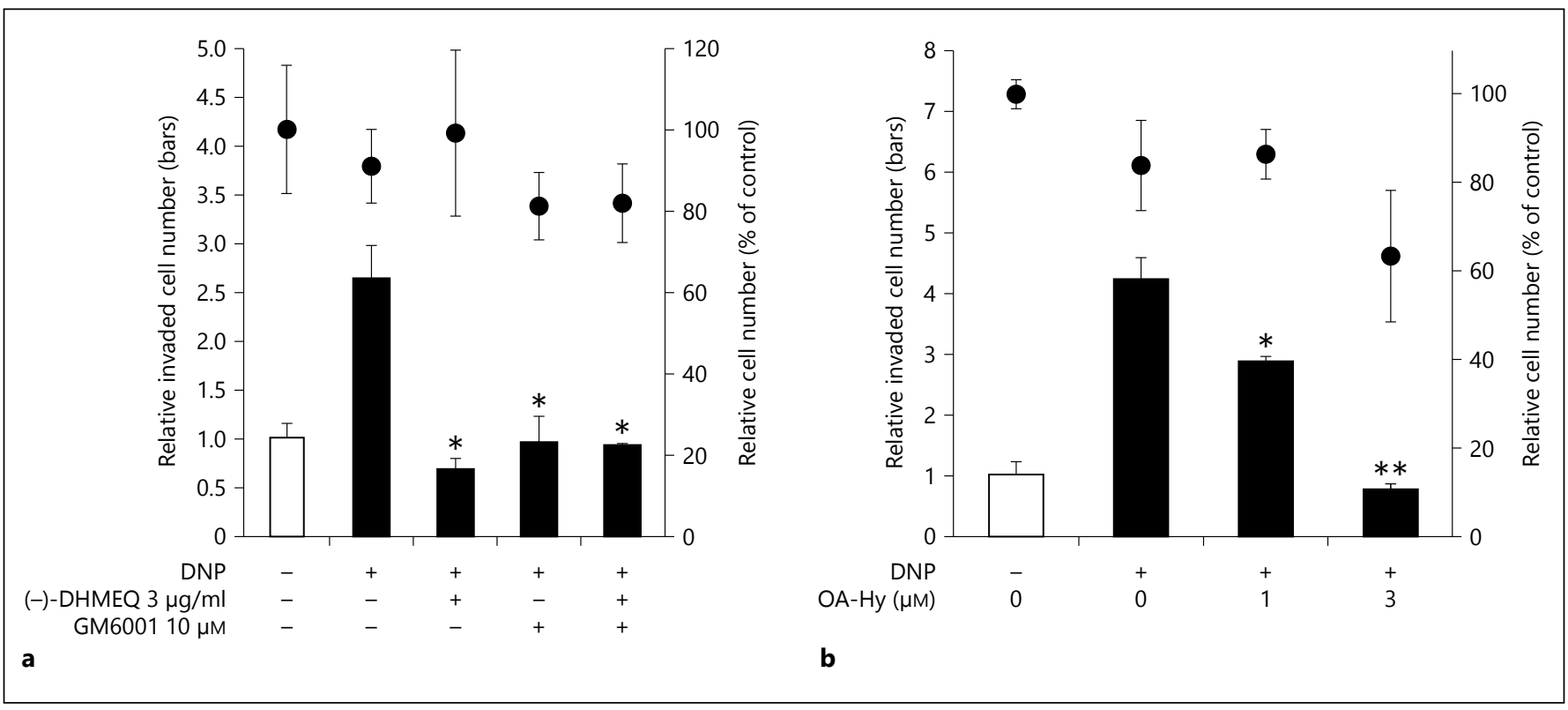

Fig. 3. Inhibition of cellular invasion by MMP inhibitors. a Inhibition by MMP inhibitor GM6001. Cellular invasion was assayed as in figure 1a using GM6001 instead of (-)-DHMEQ. Cell invasion and number are shown by the bar and dark circle, respectively. The data are the mean \pm SD of 3 independent determinations. ${ }^{*} \mathrm{p}<$ 0.05 , statistically significant differences between DNP-treated cells and DNP/inhibitor-treated cells (Student's test). b Inhibition by MMP-2 inhibitor OA-Hy. Cellular invasion was assayed as in fig- ure 1a using OA-Hy instead of (-)-DHMEQ. Cell invasion and number are shown by the bar and dark circle, respectively. The data are the mean \pm SD of 3 independent determinations. ${ }^{*} \mathrm{p}<$ 0.01 , statistically significant difference between DNP-treated cells and DNP/OA-Hy $(1 \mu \mathrm{M})$-treated cells (Student's test). ${ }^{* *} \mathrm{p}<0.001$, statistically significant difference between DNP-treated cells and DNP/OA-Hy $(3 \mu \mathrm{M})$-treated cells (Student's test).

We identified MMP-2 as a new target gene of NF- $\mathrm{kB}$ in rat basophilic leukemia RBL-2H3 cells. It is reported that the NF- $\kappa \mathrm{B}$ complex is composed of a heterodimer of p65 and p50 when activated by IgE/DNP-BSA in RBL$2 \mathrm{H} 3$ cells [19]. We observed that the band of NF- $\kappa B$ was weakened by treatment with either anti-p65 antibody or anti-RelB antibody in IgE/DNP-BSA-treated RBL-2H3 cells in the electrophoretic mobility shift assay (data not shown). Therefore, it is likely that both canonical and noncanonical NF- $\kappa \mathrm{B}$ activation pathways would be activated in RBL-2H3 cells.

Our PCR array data demonstrated that (-)-DHMEQ decreased the expression of several cell motility-related genes in RBL-2H3 cells (table 1). We focused on MMP-2 because the expression of MMP-2 has been linked with tumor invasion, angiogenesis and metastasis [23], and MMPs appear to be involved in allergic inflammation [24]. MMP-2 was detected in RBL-2H3 cells [25], but its role in $\mathrm{RBL}-2 \mathrm{H} 3$ cells remains to be revealed.

We investigated the regulation of MMP-2 mRNA transcription by luciferase promoter analysis. The rat MMP-2 promoter has an NF- $\kappa \mathrm{B}$ consensus binding site
Noma et al. 


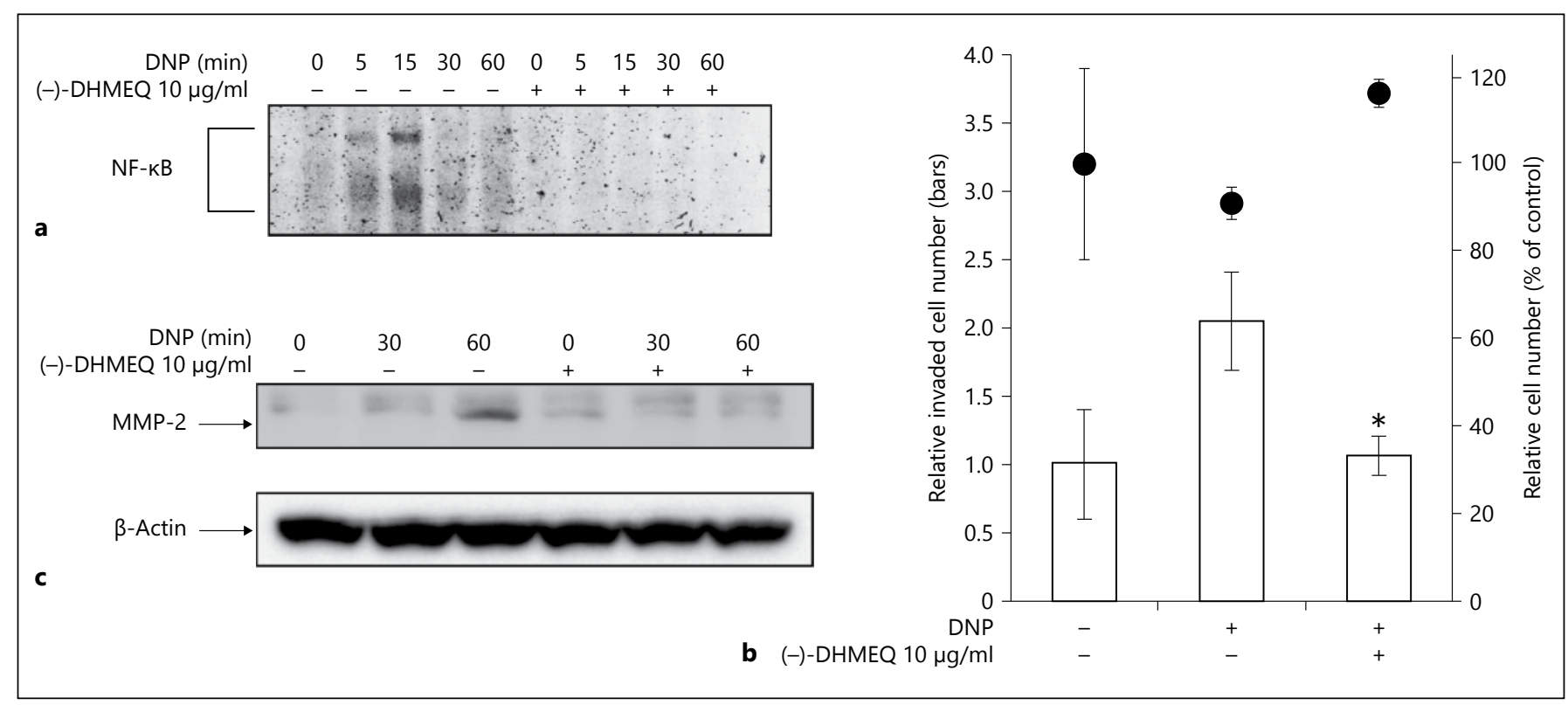

Fig. 4. Inhibition of cellular invasion and MMP-2 expression by $(-)$-DHMEQ in BMMCs. a Inhibition of NF- $\kappa$ B. BMMCs were sensitized with IgE (SPE-7) for $20 \mathrm{~h}$. The cells were treated with 10 $\mu \mathrm{g} / \mathrm{ml}(-)$-DHMEQ for $1 \mathrm{~h}$ and stimulated with DNP-BSA for the indicated period, and the nuclear proteins were extracted. Nuclear proteins were mixed with an NF- $\kappa$ B IRDye 700 oligonucleotides and applied on electrophoresis. $\mathbf{b}$ Inhibition of cellular invasion. IgE (SPE-7)-sensitized cells were seeded on the upper chamber and treated with (-)-DHMEQ for $24 \mathrm{~h}$. The lower chamber was filled with serum-free medium, with or without $100 \mathrm{ng} / \mathrm{ml} \mathrm{DNP}$ -

(-823 to $-813 \mathrm{bp}$ ). However, the MMP-2 promoter region from 1,000 bp upstream to $83 \mathrm{bp}$ downstream did not affect promoter activity in the deletion analysis. Thus, the upregulation of MMP-2 by IgE/DNP would be mediated by the complex of NF- $\mathrm{KB}$ and other transcription factors such as $\mathrm{Sp}-1$ and $\mathrm{C} / \mathrm{EBP} \beta$ that bind to another MMP-2 promoter site.

Thus, mast cell trafficking should also be regulated by IgE-independent triggers with various cytokines. Involvement of NF- $\mathrm{KB}$ in these IgE-independent mechanisms remains to be studied.

In conclusion, our findings indicate that (-)-DHMEQ suppressed mast cell migration via the inhibition of NF-
BSA. Cells that migrated to the lower side of the membrane were counted (bars). The cell number is shown as a dark circle. The data are the mean \pm SD of 3 determinations. ${ }^{*} \mathrm{p}<0.05$, statistically significant difference between DNP-treated cells and DNP/ (-)-DHMEQ-treated cells (Student's test). c Inhibition of MMP-2 protein expression. Cells were sensitized with IgE (SPE-7) for $20 \mathrm{~h}$ and treated with (-)-DHMEQ for $1 \mathrm{~h}$ and DNP-BSA for the indicated period. Total cell extracts were prepared and subjected to immunoblotting.

$\kappa \mathrm{B}$-regulated MMP-2 expression. (-)-DHMEQ may be a candidate as an antiallergy agent inhibiting mast cell accumulation.

\section{Acknowledgments}

This work was supported in part by grants from the Grants-inAid for Scientific Research programs (grant B 23310163 to K.U. and grants 24659822 and 24689056 to M.A.) from MEXT and the Keio Gijuku Fukuzawa Memorial Fund for the Advancement of Education and Research and by the MEXT-Supported Program for the Strategic Research Foundation at Private Universities, Aichi Medical University for the years 2011-2015 (S1101027).

\section{References}

1 Boyce JA: Mast cells. J Allergy Clin Immunol 2003;111:24-32.

2 Kemp SF, Lockey RF: Anaphylaxis: a review of causes and mechanisms. J Allergy Clin Immunol 2002;110:341-348.
3 Metcalfe DD, Baram D, Mekori YA: Mast cells. Physiol Rev 1997;77:1033-1079.

4 Ishizuka T, Okajima F, Ishiwara M, Iizuka K, Ichimonji I, Kawata T, Tsukagoshi $\mathrm{H}$, Dobayashi K, Nakazawa T, Mori M: Sensi- tized mast cells migrate toward the antigen: a response regulated by p38 mitogen-activated protein kinase and Rho-associated coiledcoil-forming protein kinase. J Immunol 2001; 167:2298-2304. 
5 Strouch MJ, Cheon EC, Salabat MR, Krantz SB, Gounaris E, Melstrom LG, Dangi-Garimella S, Wang E, Munshi HG, Khazaie K, Bentrem DJ: Crosstalk between mast cells and pancreatic cancer cells contributes to pancreatic tumor progression. Clin Cancer Res 2010; 16:2257-2265.

6 Ferreri NR, Howland WC, Spiegelberg HL: Release of leukotrienes $\mathrm{C} 4$ and $\mathrm{B} 4$ and prostaglandin E2 from human monocytes stimulated with aggregated IgG, IgA, and IgE. J Immunol 1986;136:4188-4193.

7 Jeong HJ, Koo HN, Na HJ, Kim MS, Hong SH, Eom JW, Kim KS, Shin TY, Kim HM: Inhibition of TNF- $\alpha$ and IL- 6 production by Aucubin through blockade of NF- $\kappa B$ activation in RBL-2H3 mast cells. Cytokine 2002;18:252259.

8 Prasad S, Ravindran J, Aggarwal BB: NF- $k B$ and cancer: how intimate is this relationship. Mol Cell Biochem 2010;336:25-37.

9 Matsumoto N, Ariga A, To-e S, Nakamura H, Agata N, Hirano S, Inoue J, Umezawa K: Synthesis of NF- $\kappa B$ activation inhibitors derived from epoxyquinomicin C. Bioorg Med Chem Lett 2000;10:865-869.

10 Suzuki Y, Sugiyama C, Ohno O, Umezawa K: Preparation and biological activities of optically active dehydroxymethylepoxyquinomicin, a novel NF- $\kappa B$ inhibitor. Tetrahedron 2004;60:7061-7066.

11 Ariga A, Namekawa J, Matsumoto N, Inoue J, Umezawa K: Inhibition of tumor necrosis factor- $\alpha$-induced nuclear translocation and activation of NF- $\mathrm{kB}$ by dehydroxymethylepoxyquinomicin. J Biol Chem 2002;277: 24625-24630.
12 Yamamoto M, Horie R, Takeiri M, Kozawa I, Umezawa K: Inactivation of NF- $\mathrm{KB}$ components by covalent binding of (-)-dehydroxymethylepoxyquinomicin to specific cysteine residues. J Med Chem 2008;51:5780-5788.

13 Wakamatsu K, Nanki T, Miyasaka N, Umezawa K, Kubota T: Effect of a small molecule inhibitor of nuclear factor- $\mathrm{kB}$ nuclear translocation in a murine model of arthritis and cultured human synovial cells. Arthritis Res Ther 2005;7:1348-1359.

14 Miyajima A, Kosaka T, Seta K, Asano T, Umezawa K, Hayakawa M: Novel nuclear factor $\mathrm{\kappa B}$ activation inhibitor prevents inflammatory injury in unilateral ureteral obstruction. J Urol 2003;169:1559-1563.

15 Abel M, Vliagoftis H: Mast cell-fibroblast interactions induce matrix metalloproteinase- 9 release from fibroblasts: role for IgE-mediated mast cell activation. J Immunol 2008; 180 : 3543-3550.

16 Girolamo ND, Indoh I, Jackson N, Wakefield D, McNeil HP, Yan W, Geczy C, Arm JP, Telda N: Human mast cell-derived gelatinase B (matrix metalloproteinase-9) is regulated by inflammatory cytokines: role in cell migration. J Immunol 2006;177:2638-2650.

17 Fenger JM, Bear MD, Volinia S, Lin TY, Harrington $\mathrm{BK}$, London $\mathrm{CA}$, Kisseberth WC: Overexpression of miR-9 in mast cells is associated with invasive behavior and spontaneous metastasis. BMC Cancer 2014;14:84.

18 Takemoto K, Hatano E, Iwaisako K, Takeiri $\mathrm{M}$, Noma N, Ohmae S, Toriguchi K, Tanabe K, Tanaka H, Seo S, Taura K, Machida K, Takeda N, Saji S, Uemoto S, Asagiri M: Necrostatin-1 protects against reactive oxygen species (ROS)-induced hepatotoxicity in acetaminophen-induced acute liver failure. FEBS Open Bio 2014;4:777-787.
19 Pelletier C, Varin-Blank N, Rivera J, Iannascoli B, Merchand F, David B, Weyer A, Blank U: FceRI-mediated induction of TNF- $\alpha$ gene expression in the RBL-2H3 mast cell line: regulation by a novel NF-kB-like nuclear binding complex. J Immunol 1998;161:4768-4776.

20 Grobelny D, Poncz L, Galardy RE: Inhibition of human skin fibroblast collagenase, thermolysin, and Pseudomonas aeruginosa elastase by peptide hydroxamic acid. Biochemistry 1992;31:7152-7154.

21 Nakamura H, Aoki M, Tamai K, Oishi M, Ogihara T, Kaneda Y, Morishita R: Prevention and regression of atopic dermatitis by ointment containing NF- $\mathrm{\kappa B}$ decoy oligodeoxynucleotides in $\mathrm{NC} / \mathrm{Nga}$ atopic mouse model. Gene Ther 2002;9:1221-1229.

22 Hamasaka A, Yoshioka N, Abe R, Kishino S, Umezawa K, Ozaki M, Todo S, Shimizu H: Topical application of DHMEQ improves allergic inflammation via NF- $\mathrm{KB}$ inhibition. J Allergy Clin Immunol 2010;126:400-403.

23 Xie T-X, Wei D, Liu M, Gao AC, Ali-Osman F, Sawaya R, Huang S: Stat3 activation regulates the expression of matrix metalloproteinase- 2 and tumor invasion and metastasis. Oncogene 2004;23:3550-3560.

24 Page K, Ledford JR, Zhou P, Wills-Karp M: A TLR2 agonist in German cockroach frass activates MMP-9 release and is protective against allergic inflammation in mice. J Immunol 2009;183:3400-3408.

25 Maxová $\mathrm{H}$, Bačáková L, Lisá $\mathrm{V}$, Novotná $\mathrm{J}$, Tomášová H, Vízek M, Herget J: Production of proteolytic enzymes in mast cells, fibroblasts, vascular smooth muscle and endothelial cells cultivated under normoxic or hypoxic conditions. Physiol Res 2010;59:711-719. 